\title{
Proceeding
}

Supplementary Issue: Winter Conferences of Sports Science. Costa Blanca Sports Science Events, 25-26 January 2019.

Alicante, Spain

\section{Experimental pedagogy: New technologies}

\author{
DAVIDE DI PALMA, ROBERTA ROSA $\triangle$, ANTONIO ASCIONE \\ Department of Motor and Well-being Sciences, University Parthenope of Naples, Italy
}

\begin{abstract}
Technological innovations concern a new opportunity for experimental pedagogical development in any school and formative context. This statement is reflected in the didactic dimension of motor and sports sciences. The main objective of this contribution is to analyse the so called "exergames" as an innovative proposal to be included in the formative offer, in motor and sports fields, of the school system in order to guarantee a more effective didactic approach. In this regard, through a review of the scientific reference literature, the pedagogical benefits on students in terms of increased level of learning and motivation to study will be framed. Key words: Technology; Exergames; Experimental pedagogy; School system; Motor and sports didactics.
\end{abstract}

\section{Cite this article as:}

Di Palma, D., Rosa, R., \& Ascione, A. (2019). Experimental pedagogy: New technologies. Journal of Human Sport and Exercise, 14(2proc), S149-S158. doi:https://doi.org/10.14198//hse.2019.14.Proc2.01

Corresponding author. Department of Motor and Well-being Sciences, University Parthenope of Naples, Naples, Italy. E-mail: robertarosa68@gmail.it

Supplementary Issue: Winter Conferences of Sports Science. Costa Blanca Sports Science Events, 25-26 January 2019. Alicante, Spain.

JOURNAL OF HUMAN SPORT \& EXERCISE ISSN 1988-5202

(c) Faculty of Education. University of Alicante.

doi:10.14198/jhse.2019.14.Proc2.01 


\section{INTRODUCTION}

Technology is increasingly present in all human actions, especially for school-age young people who are more and more inclined to acquire information and knowledge by means of such mechanisms. In fact, from the very first years of life, the ability to use technological supports is easily developed, and with them, it has become possible to stimulate learning processes. The reflection on the pedagogical and didactic systems appears, in fact, as one of the most relevant themes; technological innovations are changing ways, forms and containers of knowledge. This contribution, in this perspective, will focus on the use of a specific technology, i.e. videogames, in order to investigate their real extent to which they increase the levels of motivation and didactic learning increase. More specifically, the focus will be on the motor and sports dimensions in the second level education school context.

Playing videogames has now become a universal reality that brings together great part of world cultures. In the US context, young people playing videogames aged between 10 and 18 are more than the $80 \%$ of the total, while this figure in Italy is even close to the 90\% (Eurispes, 2012; Vivanet, 2013). It therefore does not seem strange that, recently, many educational sciences operators have been using videogames as potential tools for improving didactics. In particular, a dimension full of perspectives, and at the same time of contradictions, concerns the use of this tool in the motor and sports education didactics, where the potentialities of the use of videogames for the spatial skills learning, the recognition of cognitive patterns, the improvement of selective attention and problem-solving skills is now recognized (Sheff, 1994). Despite this, there are many concerns that school world in general, and motor and sports education in particular, have towards the use of the videogames for learning. These concerns are the result of a general and widespread distrust based on the concept that the time spent using videogames is categorized as a sedentary activity, and consequently it is closely related to obesity. This generalization, however, is misleading as it does not take into account the differences that can be found in the various types of videogames. In fact, in this regard, it is good to specify that the use of this tool for pedagogical and didactic purposes in motor and sports sciences refers to the videogames belonging to the category of the exergames (Mears \& Hansen, 2009). This category, also defined with the term "active games", "interactive games" or "active videogames", refers to those videogames that employ exercise and motor and sports activities as an input for the game. In particular, the commitment required must involve movements of the whole body to participate in virtual sports competitions, group fitness or other interactive physical activities (Sall \& Grinter, 2007). These have peculiar characteristics that make them very different from most other videogames; in fact, a lot of scientific research has identified these videogames as a tool to counteract the condition of sedentariness, with a consequent advantage in the educational and socio-health action to fight against obesity (Goldfield, Cameron \& Chaput, 2014; Lu, Kharrazi, Gharghabi \& Thompson, 2013). In the school context, the fight against obesity is an important but indirect goal: the time dedicated to motor education is obviously insufficient to be able to think about directly influencing obesity. Through school, however, it is possible to educate and stimulate behaviours that favour fitness maintenance, including a healthy Body Mass Index (BMI), such as the desire to practice sports, the awareness of the importance of movement, and the mastery of motor and coordination skills. These aspects can be conveyed through school education, and can benefit from alternative tools such as videogames in general, and exergames in particular. In this regard, after summarizing the characteristics of the exergames, the potential positive and negative effects for didactics will be highlighted, and then, through an experimental project carried out in a school context, their real effectiveness and consequent possible use in motor and sports education classes will be analysed. 


\section{Structural characteristics of the Exergames in its adaptability to the School System}

In order to evaluate concretely the possibility of including the exergames in a school motor and sports educational program, it is essential to analyse a priori what are the structural characteristics that can support this choice. Like all videogames, the exergames are based on a series of challenges linked by a cause-effect relationship in a simulated environment, which, if cleverly structured, allow the player getting into a state of "flow", in which the intrinsic motivation, the positivity in acting and the involvement levels are very high, with the result that the player is completely into the game. The succession of challenges must be cleverly structured so as to obtain a correct mediation with the skills necessary to overcome them. The key factors to obtain a good balance between the level of difficulty and the necessary skills are the presence of clear objectives and immediate feedbacks, the conveyance of a sense of controllability with respect to success and playability. In addition to these factors, the exergames must take into account the correlation between the necessary intensity and the level of fitness required to achieve the goal of the game. Both components must be well balanced in order to guarantee a level of involvement that keeps the player (and therefore the potential student) focused and motivated to complete what the game requires. An exergame player can be thought of as an onscreen producer of content (Salman \& Calvert, 2011) - a person who, through his own body movements, produces and controls the movements on the screen. The exergames are therefore able to interpret the movements of the player's body as impulses associated with specific meanings of the game, reproducing the movements in a three-dimensional space on a two-dimensional screen. The distance between the player and the character on the screen, if from a "playability" perspective could be a limitation, in terms of pedagogical and educational development in the motor and sports sciences must instead be considered as the stimulus for the player-student to develop basic skills, such as:

- High visual-spatial skills;

- Good eye-hand and eye-foot coordination;

- Low reaction time in very often complex stimuli and with multiple response alternatives.

Moreover, the possibility of playing in a multi-player modality, both in cooperation and in competition, guarantees a real interaction in addition to the virtual one, stimulating some of the pedagogical sports principles such as "team working" and healthy competition. (Staiano \& Calvert, 2011). These first considerations make some important characteristics of the exergames clear, which seem potentially able to influence also the three domains of learning: cognition, affective and psychomotor sphere.

The potential effects of the Exergames in the Educational Sciences of the Motor and Sports Sphere From a review of the main reference literature, although still limited, it emerges that, in a school perspective with main reference to motor and sports education, the exergames potentially have the ability to positively influence the player-student (Fery \& Ponserre, 2001; Höysniemi, 2006; Mueller, Agamanolis \& Picard, 2003; Staiano \& Calvert, 2011; Unnithan, Houser \& Fernhall, 2006; Vaghetti et al, 2018):

- From a motor-sport perspective;

- From a coordination perspective;

- From a cognitive perspective;

- From a social perspective. 
Table 1. Potential Positive Effects of the Exergames for the Player-Student

\begin{tabular}{|c|c|c|c|c|}
\hline & \multicolumn{4}{|c|}{ PERSPECTIVE } \\
\hline & MOTOR-SPORTS & COORDINATIVE & COGNITIVE & SOCIAL \\
\hline $\begin{array}{c}\text { POTENTIAL } \\
\text { POSITIVE } \\
\text { EFFECTS FOR } \\
\text { THE PLAYER- } \\
\text { STUDENT }\end{array}$ & $\begin{array}{l}\text { - A caloric burn rate } \\
\text { and a heart rate } \\
\text { comparable to light } \\
\text { and moderate } \\
\text { activity (walking at } \\
4.5 \mathrm{~km} / \mathrm{h} \text { ) in } \\
\text { adolescents; } \\
\text { - A burn rate that is } \\
\text { more than twice the } \\
\text { normal rate, } \\
\text { compared to } \\
\text { traditional } \\
\text { videogames; } \\
\text { - General fitness } \\
\text { benefits; } \\
\text { - Weight loss. } \\
\text { - Team working } \\
\text { stimulus } \\
\text { - Healthy } \\
\text { competition } \\
\text { stimulus }\end{array}$ & $\begin{array}{l}\text { - Improved Ocular- } \\
\text { manual } \\
\text { coordination; } \\
\text { - Improved } \\
\text { dexterity; } \\
\text { - Improved motor } \\
\text { skills. }\end{array}$ & $\begin{array}{c}\text { - School } \\
\text { performance } \\
\text { general } \\
\text { improvement thanks } \\
\text { to a high } \\
\text { conveyance of } \\
\text { acquired skills; } \\
\text { - Spatial awareness } \\
\text { stimulus; } \\
\text { - Attention stimulus; } \\
\text {-Cause-effect } \\
\text { relationships; } \\
\text { - Understanding and } \\
\text { spatial constraints } \\
\text { stimulus; } \\
\text { - Ability to respond } \\
\text { to visual inputs } \\
\text { stimulus; } \\
\text { - Creating cognitive } \\
\text { maps of the body } \\
\text { movements used } \\
\text { stimulus. }\end{array}$ & $\begin{array}{l}\text { - Decreased isolation } \\
\text { risk; } \\
\text { - Increased friendship } \\
\text { relationships, both those } \\
\text { face-to-face and those } \\
\text { generated } \\
\text { online/interactive on the } \\
\text { multiple social networks } \\
\text { challenge; } \\
\text { - Increased levels of self- } \\
\text { efficacy and self-esteem; } \\
\text { - Improved mood }\end{array}$ \\
\hline
\end{tabular}

Source: Our Elaboration from Reviewed Literature

It should be noted that this type of videogame allows synergistically relating both the cognitive improvements due to the use of videogames, and those related to the practice of motor and sports activities, characterizing itself as a valuable learning tool (Staiano \& Calvert, 2011).

Moreover, compared to traditional videogames, the exergames allow for greater interactivity between players, making a live multiplayer gaming possible in a context very similar to the real one. Furthermore, evidence from the reference literature shows how exergames can positively influence judgment with respect to motor activities (Goldfield, Kalakanis, Ernst \& Epstein, 2000). In all the studies analysed, increased students' motivation, participation and commitment level can be observed (Papastergiou, 2009; Paw et al., 2008; Sun, 2012). In the specific case of motor education, the increased motivation to motor practice during school lessons is important, since it translates into the persistence of motor practice over time. In this regard, while recalling that the exergames are primarily games, they preserve the characteristic of an activity as an end in itself, and which finds fulfilment and gratification in the action of playing itself; this should lead to exploit this characteristic to help pedagogical operators stimulate the intrinsic motivation of learning, which is often difficult to obtain. For example, activities for the development of conditional skills, which are often unattractive to students, could make use of the motivational component of videogames (Killi and Perttula 2010, Maivorsdotter \& Quennerstedt, 2018, Prensky, 2002). Another fundamental point that characterizes motivation is the perception of the competence that develops from the interpretation of one's own episodes 
of success and failure, the type of social support and the outcome of one's own attempts to master a particular motor or cognitive skill (Baranowski, Buday, Thompson \& Baranowski, 2008). In the field of school education, therefore, we refer to the importance of the concept of optimal challenge, which is one of the fundamental aspects in the development of successful videogames, in particular for the exergames, which must be challenging both from the point of view of the game in itself, and from that of the associated physical requirements. The concept of optimal challenge is one of the causes allowing the exergames being valid tools for increasing motivation to learn.

In the light of what the literature analysis highlighted, the attention shown by many operators in the field of education and motor and sports sciences, compared to the use of exergames as a tool for didactics, does not seem strange. In particular, the use of exergames during motor education classes is certainly a perspective full of attraction, so as to encourage the development of specific exergames for didactics.

\section{Experimental Design of Motor and Sports Education through the Exergames in the School System}

According to some authors, motor and sports education classes are a promising place for the use of the exergames in education (Yang, Smith \& Graham, 2008). In the United States, computers and consoles are already found in the school system, with almost half of the students declaring to use videogames to perform a didactic activity assigned at school (Lenhart, 2008), and some exergames have been introduced into the motor and sports education curricula. For example, the "Dance dance revolution" game was introduced into the curriculum as an example of activity belonging to the category of "rhythmic activities". However, it is important to remember that the objective of this paper is not to propose the exergames as a substitute for the current proposal of Motor and Sports Education but, like any other type of technology, it proposes to consider them as complementary tools of an effective practice. In this regard, an experimental project in the pedagogical-didactic field implemented in a second-level education school class context is described to evaluate the effectiveness and the effects in the practice of a motor and sports didactics educational program involving the combination of traditional methods with the use of exergames.

\section{METHOD}

It is essential to state that the experimentation was based on the collaboration and expertise of the motor and sports education teacher of the "sample" class, which was the object of the project.

Didactic Discipline: Motor and Sports Education.

The sample consisted of 22 second-year students of a second grade educational institution: 16 males (M) 6 females (F) - average age: 14.8 years. A subdivision into 2 homogeneous groups was carried out by gender and starting level:

Experimental Group: 8 M - 3 F; Sample group: 8 M - 3 F.

Duration: 3 Months - 2 Weekly Lessons of 1 hour each - For a total of 24 Lessons (24 hours).

Maximum number of hours of absence for the student to be considered valid element in the experimentation: 2 hours.

Exergames used: Dance Dance Revolution -. Your Shape Fitness Evolved - EA Sports Active 2 - Just Dance. 
Table 2. Evaluation Protocol

\begin{tabular}{|c|c|c|c|c|c|c|}
\hline $\begin{array}{l}\text { FOUNDING } \\
\text { NUCLEI }\end{array}$ & \multicolumn{2}{|c|}{$\begin{array}{c}\text { THE BODY, ITS } \\
\text { EXPRESSIVENESS AND } \\
\text { THE CONDITIONAL } \\
\text { SKILLS }\end{array}$} & \multicolumn{2}{|c|}{$\begin{array}{l}\text { THE SENSORY } \\
\text { PERCEPTION, THE } \\
\text { MOVEMENT AND ITS } \\
\text { RELATIONSHIP WITH } \\
\text { SPACE AND TIME }\end{array}$} & \multicolumn{2}{|c|}{$\begin{array}{l}\text { GAME, GAME-SPORTS, } \\
\text { SPORTS }\end{array}$} \\
\hline SKILLS & \multicolumn{2}{|c|}{$\begin{array}{l}\text { Performing motor activities by } \\
\text { adapting to different contexts } \\
\text { and expressing actions through } \\
\text { gestures. }\end{array}$} & \multicolumn{2}{|c|}{$\begin{array}{l}\text { Using perception stimuli to } \\
\text { achieve the required motor action } \\
\text { in a suitable and effective way. }\end{array}$} & \multicolumn{2}{|c|}{$\begin{array}{l}\text { Knowing and practicing, in the } \\
\text { correct and essential way, the } \\
\text { main sports games and } \\
\text { individual sports }\end{array}$} \\
\hline \multirow[b]{2}{*}{$\begin{array}{l}\text { KNOWLEDGE } \\
\text { AND SKILLS }\end{array}$} & Knowledge & Skills & Knowledge & Skills & Knowledge & Skills \\
\hline & $\begin{array}{l}\text { Knowing the } \\
\text { potentialities of } \\
\text { the movement of } \\
\text { one's body, the } \\
\text { correct postures } \\
\text { and the } \\
\text { physiological } \\
\text { functions. } \\
\text { Recognizing the } \\
\text { rhythm of actions } \\
\text { and the } \\
\text { difference } \\
\text { between } \\
\text { functional and } \\
\text { expressive } \\
\text { movement. }\end{array}$ & $\begin{array}{l}\text { Developing } \\
\text { effective } \\
\text { and } \\
\text { personal } \\
\text { motor } \\
\text { responses } \\
\text { in simple } \\
\text { situations. } \\
\text { Taking } \\
\text { correct } \\
\text { postures at } \\
\text { natural } \\
\text { load } \\
\text { carriage. } \\
\text { Seizing } \\
\text { rhythmic } \\
\text { differences } \\
\text { in simple } \\
\text { motor } \\
\text { actions. }\end{array}$ & $\begin{array}{l}\text { Knowing about } \\
\text { the system of } \\
\text { motor skills that } \\
\text { underlies motor } \\
\text { and sports } \\
\text { performance. }\end{array}$ & $\begin{array}{c}\text { Having } \\
\text { awareness of } \\
\text { an effective } \\
\text { and } \\
\text { affordable } \\
\text { motor } \\
\text { response. } \\
\text { Managing the } \\
\text { start-up } \\
\text { phase } \\
\text { independently } \\
\text { according to } \\
\text { the chosen } \\
\text { activity. }\end{array}$ & $\begin{array}{l}\text { Knowing about } \\
\text { the essential } \\
\text { aspects of sports } \\
\text { terminology, } \\
\text { regulation and } \\
\text { technique. }\end{array}$ & $\begin{array}{c}\text { Knowing } \\
\text { about and } \\
\text { practicing } \\
\text { essential } \\
\text { sports } \\
\text { games } \\
\text { and some } \\
\text { individual } \\
\text { sports in } \\
\text { an } \\
\text { essential } \\
\text { and } \\
\text { correct } \\
\text { way. }\end{array}$ \\
\hline STANDARD & \multicolumn{2}{|c|}{$\begin{array}{l}\text { Being aware of the } \\
\text { morphological and functional } \\
\text { body changes. Expressing } \\
\text { oneself through technical } \\
\text { gestures }\end{array}$} & \multicolumn{2}{|c|}{$\begin{array}{l}\text { Controlling and adjusting the } \\
\text { movements referred to oneself } \\
\text { and the environment to solve a } \\
\text { motor task, by using sensory } \\
\text { information. }\end{array}$} & \multicolumn{2}{|c|}{$\begin{array}{l}\text { Performing the technical } \\
\text { gestures in a simplified game } \\
\text { situation by respecting the } \\
\text { rules, covering different roles } \\
\text { (i.e. a referee) and recognizing } \\
\text { the value of the competition. }\end{array}$} \\
\hline LEVEL 1 & \multicolumn{2}{|c|}{$\begin{array}{c}\text { Sufficiently implements the } \\
\text { adaptations referred to a } \\
\text { habitual motor activity and to } \\
\text { elements belonging to a tested } \\
\text { field }\end{array}$} & \multicolumn{2}{|c|}{$\begin{array}{l}\text { Sufficiently recognizes various } \\
\text { sensory information and controls } \\
\text { the gesture in relation to spatial - } \\
\text { temporal changes }\end{array}$} & \multicolumn{2}{|c|}{$\begin{array}{l}\text { Knows sufficiently the rules } \\
\text { and techniques of practiced } \\
\text { sports and participates with fair } \\
\text { play, by also facing arbitration } \\
\text { functions }\end{array}$} \\
\hline LEVEL 2 & \multicolumn{2}{|c|}{$\begin{array}{l}\text { Performs different motor } \\
\text { actions, correctly uses } \\
\text { proposed models by testing his } \\
\text { skills even in experimental } \\
\text { settings }\end{array}$} & \multicolumn{2}{|c|}{$\begin{array}{l}\text { Can identify sensory information } \\
\text { by implementing correct motor } \\
\text { responses while respecting } \\
\text { movement dynamics. }\end{array}$} & \multicolumn{2}{|c|}{$\begin{array}{l}\text { Knows the tactics and } \\
\text { possesses good skills in } \\
\text { various sports activities, } \\
\text { showing fair play and respect } \\
\text { for the rules }\end{array}$} \\
\hline LEVEL 3 & \multicolumn{2}{|c|}{$\begin{array}{l}\text { Shows excellent knowledge } \\
\text { and realizes different motor } \\
\text { activities in a harmonious way } \\
\text { adapted to the situations }\end{array}$} & \multicolumn{2}{|c|}{$\begin{array}{l}\text { Can optimally adjust the dynamics } \\
\text { of the movement by using } \\
\text { perceptual information, } \\
\text { performing motor gestures with } \\
\text { synchronized movement. }\end{array}$} & \multicolumn{2}{|c|}{$\begin{array}{c}\text { Shows tactical confidence, fair } \\
\text { play and excellent skills in the } \\
\text { practice of various sports } \\
\text { activities }\end{array}$} \\
\hline
\end{tabular}

Source: Our Elaboration. 
The Experimental Group included, in its didactic program, the use of the exergames for a $50 \%$ of the lesson hours through a teaching strategy that employed a Rink "station teaching" directive strategy (2002). In the meanwhile, the Sample Group carried out the traditional Motor and Sports Education program.

The Evaluation Protocol employed, structured in collaboration with the teacher who also had previous knowledge of the entire sample, is summarized in the following outline and is contextualized to the grade and academic year of the class taken as a research sample.

The protocol provides for 3 levels of judgment in increasing order, from the first to the last. In synergy with the teacher, 2 evaluations were carried out: the first at time 0 (before starting the three-month project) and the second (at time 1) at the end of the project, both for the experimental group and for the con trol one, in order to monitor the educational development of students in both cases.

\section{Outcomes and Observations}

Table 3. Evaluation at Time 0

\begin{tabular}{cccc}
\hline STUDENT & LEVEL & STUDENT & LEVEL \\
\hline C1F & 1 & E1F & 1 \\
C2F & 1 & E2F & 1 \\
C3F & 1 & E3F & 1 \\
C4M & 1 & E4M & 1 \\
C5M & 1 & E5M & 1 \\
C6M & 1 & E6M & 1 \\
C7M & 1 & E7M & 1 \\
C8M & 1 & E8M & 1 \\
C9M & 2 & E9M & 2 \\
C10M & 1 & E10M & 1 \\
C11M & 2 & E11M & 2 \\
\hline
\end{tabular}

Source: Our Elaboration.

Table 4. Evaluation at Time 1

\begin{tabular}{cccc}
\hline STUDENT & LEVEL & STUDENT & LEVEL \\
\hline C1F & 2 & E1F & 2 \\
C2F & 1 & E2F & 2 \\
C3F & 1 & E3F & 2 \\
C4M & 2 & E4M & 2 \\
C5M & 2 & E5M & 1 \\
C6M & 1 & E6M & 2 \\
C7M & 1 & E7M & 1 \\
C8M & 2 & E8M & 2 \\
C9M & 3 & E9M & 3 \\
C10M & 1 & E10M & 1 \\
C11M & 2 & E11M & 3 \\
\hline
\end{tabular}

Source: Our Elaboration.

Below the tables at time 0 and 1 with the related assessment for each student, based on observation and verification according to the typical canons adopted by the motor and sports education teacher, for the context 
and the degree of the research sample. To code the subject, the prefix "E" was employed for the experimental group, and the prefix " $\mathrm{C}$ " for the control group; the boys were randomly numbered from 1 to 11 and the letter "M" was employed for males, and "F" for females.

First of all, it should be noted that no student exceeded the 2-hour absence limit, so the experimental phase dropout is 0 . No student of both groups gained a double level jump, probably due to the limited time. In the control group, 5 students showed formative growth thanks to the traditional didactic plan (45.45\%), while in the experimental group, the project including the use of the exergames allowed 8 students achieving an educational development $(72.72 \%)$.

The didactic outcome, however, must be considered with caution due to the reduced number of the sample, its homogeneity in the school environment and the limited duration of the experimentation phase, but it certainly confirms the didactic and pedagogical potentiality of an educational offer in the motor and sports sciences that brings traditional technological elements of the exergames together with traditional methodologies.

In this regard, future research points could be precisely the increase in the number of the sample and its differentiation, both in terms of the level of education and in terms of the type and specialisation of the school context; in this way, an optimal didactic strategy could be analysed in terms of combination and synergy between traditional and technological tools.

\section{CONCLUSIONS}

The conscious, targeted and organized use of the exergames during motor and sports education classes can be an innovative component for the didactic proposal of the school system. The experimentation carried out is fully consistent with the studies analysed on the topic, and is favourable to employing the exergames in didactics as a tool for learning and training development in the school system. An aspect of primary importance is certainly the positive effect of this tool on the motivational component, especially when there are direct educational strategies that, being naturally characterized by a prevalence of behaviours oriented to the Self, i.e. based on normative comparison, often lead to a general reduced motivation. It is clear that the proposal to combine this technological tool with the traditional didactic approach in motor and sports sciences can lead to a more efficient educational action of the school system. Moreover, by combining the typical attractiveness of videogames with the motor and sports component, the exergames can become a useful tool for the construction of an active lifestyle which lasts over time, emphasizing and stimulating the pedagogical values of the recreational component and of the amusement in motor and sports activities. This contribution is a solid basis for the development of future empirical research to assess the effectiveness, in the medium-long term, of the exergames and the related educational and didactic strategy that optimizes their adoption in the education system contexts of all levels.

\section{CONTRIBUTIONS}

The manuscript is the result of a collective work of the authors, the specific contribution of which is to be referred to as follows: the Introduction and Paragraph $\mathrm{n}$. 1 is to be attributed to Roberta Rosa, Paragraph $\mathrm{n}$. 2 and the Conclusions to Antonio Ascione, Paragraph n. 3 to Davide Di Palma. 


\section{REFERENCES}

Baranowski, T., Buday, R., Thompson, D.I., \& Baranowski, J. (2008). Playing for real: video games and stories for health-related behavior change. American Journal of Preventive Medicine, 34, 74-82. https://doi.org/10.1016/.amepre.2007.09.027

Eurispes (2012). Indagine conoscitiva sulla condizione dell'infanzia e dell'adolescenza in Italia. Roma: Eurispes.

Fery, Y., \& Ponserre, S. (2001). Enhancing the control of force in putting by video game training. Ergonomics, 44, 1025-1037. https://doi.org/10.1080/00140130110084773

Goldfield, G.S., Cameron, J.D., \& Chaput, J.P. (2014). Is Exergaming a viable tool in the fight against childhood obesity?. Journal of Obesity. https://doi.org/10.1155/2014/304521

Goldfield, G.S., Kalakanis, L.E., Ernst, M.M., \& Epstein, L.H. (2000). Open-loop feedback to increase physical activity in obese children. International Journal of Obesity, 24, 888-892. https://doi.org/10.1038/si.ijo.0801248

Kiili, K. and Perttula, A., 2010. Exergaming: Exploring engagement principles. In the proceedings of the Serious games for sports and Health, Game Days 2010. Darmstadt, Germany. pp. 161-172.

Lenhart, A. (2008). Teens, video games, and civics. Washington, DC: Pew Internet \& American Life Project.

Lu, A.S., Kharrazi, H., Gharghabi, F., \& Thompson, D. (2013). A systematic review of health videogames on childhood obesity prevention and intervention. Games For Health Journal: Research, Development, and Clinical Applications, 2(3), 131- 141. https://doi.org/10.1089/g4h.2013.0025

Maivorsdotter, N., \& Quennerstedt, M. (2018). Exploring gender habits: A practical epistemology analysis of exergaming in school. European Physical Education Review. https://doi.org/10.1177/1356336X18810023

Mears, D., \& Hansen, L. (2009). Technology in Physical Education article \#5 in a 6-part series: active gaming: definitions, options and implementation. Strategies, 23(2), 26-29. https://doi.org/10.1080/08924562.2009.10590864

Mueller, F., Agamanolis, S., \& Picard, R. (2003). Exertion interfaces: sports over a distance for social bonding and fun. Proceedings of the SIGCHI conference on human factors in computing systems, 561-568. https://doi.org/10.1145/642611.642709

Papastergiou, M. (2009). Exploring the potential of computer and video games for health and physical education: a literature review. Computers \& Education, 53, 603- 622. https://doi.org/10.1016/j.compedu.2009.04.001

Paw, M.J.C.A., Jacobs, W.M., Vaessen, E.P., Titze, S., \& van Mechelen, W. (2008). The motivation of children to play an active video game. Journal of Science and Medicine in Sport, 11(2), 163-166. https://doi.org/10.1016/i.jsams.2007.06.001

Prensky, M. (2002). The motivation of gameplay, or, the REAL 21st century learning revolution. On the Horizon, 10(1), 1-14. https://doi.org/10.1108/10748120210431349

Rink, J.E. (2002). Teaching physical education for learning (4th ed.). New York, NY: McGraw-Hill.

Sall, A., \& Grinter, R.E. (2007). Let's get physical! In, out and around the gaming circle of physical gaming at home. Computer Supported Cooperative Work, 16, 199-229. https://doi.org/10.1007/s10606-007$\underline{9047-2}$

Sheff, D. (1994). Video games: a guide for savvy parents. New York, NY: Random House.

Staiano, A.E., \& Calvert, S.L. (2011). Exergames for Physical Education courses: physical, social, and cognitive benefits. Child Developmental Perspective, 5(2), 93-98. https://doi.org/10.1111/j.1750$\underline{\text { 8606.2011.00162.x }}$ 
Sun, H. (2012). Exergaming impact on physical activity and interest in elementary school children. Research Quarterly for Exercise and Sport, 83(2), 212-220. https://doi.org/10.1080/02701367.2012.10599852

Unnithan, V.B., Houser, W., \& Fernhall, B. (2006). Evaluation of the energy cost of playing a dance simulation video game in overweight and non-overweight children and adolescents. International Journal of Sports Medicine, 27(10), 804- 809. https://doi.org/10.1055/s-2005-872964

Vaghetti, C. A. O., Monteiro-Junior, R. S., Finco, M. D., Reategui, E., \& da Costa Botelho, S. S. (2018). Exergames experience in physical education: A review. Physical Culture and Sport. Studies and Research, 78(1), 23-32. https://doi.org/10.2478/pcssr-2018-0010

Vivanet, G. (2013). Le ICT nella scuola italiana. Sintesi dei dati in un quadro comparativo europeo. Form@re - Open Journal per la Formazione in Rete, 13(4), 47-56.

Yang, S., Smith, B., \& Graham, G. (2008). Healthy video gaming: oxymoron or possibility?. Journal of Online Education, 4(4), 5. 